\title{
Strategic Plan for the Development of the RS Bersalin Grha Mutiara \\ in 2019-2023: Policy Implementation
}

\author{
* Melsha Syarahhandi, ** Mieke Savitri \\ * RS Bersalin Grha Mutiara Subang \\ ** Faculty of Public Health, Universitas Indonesia
}

Email :melshasyarahhandi@gmail.com

\begin{abstract}
This research discusses the Strategic Plan for the Development of the RS Bersalin Grha Mutiara in 2019-2023, using the theory of Strategic Planning to observe and evaluate external environmental opportunities and threats as well as the internal strengths and weaknesses of the hospital, to determine the right strategic plan. This study is a qualitative research using primary data, in-depth interviews with informants, observation and decision making with CDMG (Consensus Decision Making Group), and secondary data obtained from the BPS (Central Bureau of Statistics), Dinas Kesehatan Subang (District Health Office) Profile, Profile and Financial Report of RS Bersalin Grha Mutiara. From this study, the position of RS Bersalin Grha Mutiara, according to IE Matrix, is in Cell V (Hold and Maintain) and SWOT Matrix in Quadrant II (Internal Fixed It Quadrant). The matching stage resulted in a Product Development strategy, which, through the QSPM matrix, determine that the chosen strategy would be the development of HCU / NICU / PICU. This plan then elaborated in the implementation plan using the Balanced Scorecard.
\end{abstract}

Keywords: Strategic Plan, SWOT, Balanced Scorecard

\section{INTRODUCTION}

The hospital is a health service institution that conducts individual health services in a comprehensive manner providing inpatient, outpatient, and emergency services (Law No.44 of 2009 on Hospitals). Hospital, a health service facility that uses heavily on technologies and experts, plays a strategic role in accelerating the improvement of public health status. In order to survive and developed, a hospital must adapt to the growth and influence of the environment. The hospital management paradigm must be changed to be effective, efficient, and can accommodate change (Aditama, 2010).

In the Minister of Health Regulation No. 56 of 2014 concerning Hospital Classification and Licensing, the definition of Specialized Hospital is a hospital that provides primary services in one particular field or type of disease based on scientific discipline, age group, organ, gender or other specificities. In addition to the types of specialized hospitals stipulated in article 59, the Minister may stipulate other types of specialized hospitals, which can be in the form of a combination of specific types of new types of specificity based on studies and obtain recommendations from hospital associations and related professional organizations.
Based on Minister of Health Regulation No. $340 /$ MENKES / PER / III / 2010 about Hospital Classification, The classifications of Hospital are Class A, B, and C in terms of Services, Human Resources, Equipment, Infrastructure Facilities as well as Administration and Management.

With the increasing number of General Hospitals in the Subang Regency, efforts must be made to obtain and maintain sustainable competitive excellence, by continuously adapting to changes in trends and external activities and capabilities, competencies, and internal resources as well as by effectively formulating, implementing, and assessing various strategies that further strengthen these factors.

Maternity Hospital has limitations in serving maternal hospitalization with obstetrical and uterine cases as well as neonates, an effort should be made to continue to survive by always developing themselves, for example by developing into RSIA so that it can provide inpatient services for children (aged 0-14 years) or General Hospital with the addition of other types of specialist services. With the change to a General Hospital that has a variety of services, it is expected to increase both outpatient and inpatient visits. 
Changes in hospital operating permits can be made when there is a change in ownership, type of hospital, name of the hospital, and classification of the hospital. In the Regulation of the Minister of Health Number 56 of 2014 Article 79 (d), stipulated that Specialized Hospitals that use names other than those specified in article 59 paragraph 1, must adjust to the provisions no later than one year after the Regulation of the Minister of Health is promulgated.

The purpose of this study is to formulate appropriate strategic planning in the development of Graha Mutiara Maternity Hospital with a strategic planning approach from Fred R. David through external and internal situation analysis. Analysis using this Balance Scorecard approach can identify strengths, weaknesses, opportunities, threats, and strategic positions, to produce several alternative strategy recommendations and translate the selected strategy into a work program.

\section{Literature Review}

Strategic management, according to David (2010), is the art and knowledge in formulating, implementing, and evaluating cross-functional decisions that enable an organization to achieve its goals. So from that understanding, strategic management focuses on efforts to integrate management, marketing, finance, production/operations, research, and development as well as computer information systems to achieve organizational success.

According to Hunger and Wheelen (2003), strategic management is a series of managerial decisions and actions that determine the company's performance in the long term, which includes environmental observation, strategy formulation, strategy implementation, and evaluation and control. Strategic management as a field of science that combines business policy with the environment and strategic pressure.

The benefits of strategic management, according to David (2010), for financial and non-financial, allows an organization to be more productive in directing and influencing various activities, thereby controlling its destiny. Strategic management helps organizations formulate better strategies through approaches to strategy choices that are more systematic, logical, and rational. Businesses that adopt strategic management show improvements in sales, profitability, and productivity, usually showing relatively better longterm financial performance. In addition to avoiding financial disasters, strategic management offers other tangible benefits such as raising awareness of external threats, improving understanding of competitor strategies, increasing employee productivity, decreasing resistance to change, and a clearer understanding of the reward performance relationship.
Essential strategy formulation techniques can be integrated into a three-stage decision-making framework consisting of stage 1, the Input Stage containing the necessary information needed to formulate a strategy.

Stage 2, the Matching Stage, focuses on creating alternative strategies that make sense by taking into account the main external and internal factors, including the Strength-Weakness-Opportunities-Threats-ThreatsSWOT matrix, Strategic Position and Action Evaluation (SPACE), Boston Consulting Group (BCG) Matrix, Internal-External Matrix (IE).

Stage 3, the Decision Stage, involves only one technique, the Quantitative Strategic Planning Matrix (QSPM), showing the relative attractiveness of various alternative strategies, thus providing an objective basis for the selection of alternative strategies.

The Balanced Scorecard consists of two words: (1) a scorecard and (2) balanced. Balanced Scorecard uses four perspectives in measuring performance which are financial perspective, customers, internal business processes, and learning and growth (Kaplan and Norton, 2000)

The role of the Balanced Scorecard in the programming and budgeting stages of making strategic objectives that are formulated comprehensively in the strategic planning stage will motivate personnel to look for various strategic initiatives in realizing these broad strategic goals. The role of the Balanced Scorecard in the implementation phase is used for personnel performance in four perspectives, which are finance, customers, business processes, and learning and growth. While at the monitoring stage, the results of performance measurements of personnel in the four perspectives are compared with targets set in the budget and targets set in strategic planning. (Ayuningtyas, 2015)

\section{Methods}

This study is an Operational Research with qualitative data analysis which analyzes external and internal conditions in the development plan of the Grha Mutiara Maternity Hospital. Data and information used in this study were primary data and secondary data. Primary data were collected qualitatively by conducting in-depth interviews (in-depth interviews) and CDMG (Consensus Decision Making Group). Secondary data were collected from the Subang Regency BPS, Subang District Health Office, internal data from the Grha Mutiara Maternity Hospital. The study was conducted at RSB Grha Mutiara on Jln. Brigadier General Katamso No. 4 Subang. The study began on 30 November 2018 1 June 2019. 
This study uses the theory of strategic planning from Fred R. David with modifications to adjust the conditions of the hospital where the study. After the primary and secondary data were collected, then data analysis proceeds as follows:

\section{a. Input Stage}

The data were grouped according to the variables, then the results of data processing are conveyed in the CDMG to identify the factors that become opportunities, threats, strengths, and weaknesses then determine the critical success factors.

\section{b. Matching Stage}

This stage is divided into two stages. First is the matching stage with two matrices (TOWS Matrix and IE Matrix) to determine the position of competitiveness along with strategy recommendations. Then the second stage is asking the CDMG members to provide input on the possibility of developing the Grha Mutiara Maternity Hospital with proposed alternative activities following the recommendations of the strategy.

\section{c. Decision Stage}

CDMG will determine the possibility of developing Grha Mutiara Maternity Hospital. Several alternative activities will be analyzed using QSPM analysis based on priorities by making a list of critical factors taken directly from the IE matrix and then assigning points to each of the external and internal factors. The process then followed by determining the value of attractiveness (Attractiveness Score), which indicates the relative attractiveness of one activity against other activities.

\section{d. Implementation Plan Stage}

After using the QSPM matrix priority to determine the strategy, then the strategy elaborated in the work program along with the KPI and its size with four Perspectives from the Balanced Scorecard, which are financial, customer, internal business and learning growth perspectives.

\section{Results}

In this section, we will discuss the results of the research consisting of the Input Stage, which is the analysis of external and internal factors, the Matching Stage, which consists of the IE Matrix, the TOWS Matrix, Position and the determination of Alternative Strategies. In the Decision Stage (Decision Stage), which consists of determining the chosen strategy and decision making with QSPM, then finally for the Strategy Implementation Plan with the Balanced Scorecard approach for the next five years.
External factors that will be assessed are Government Policy, Geography, Demography, Epidemiology, Economy, Education, Technology, Competitors, Suppliers, and Customers.

After identifying external factors, the variables will be grouped as an opportunity or threat to the development of Grha Mutiara Maternity Hospital through CDMG with the Director and the Head of the Department.

Critical success factors that exist will be given a point that ranges from 0.0 (not important) to 1.0 (very important). This point indicates the relative significance of a factor in the company's success. The amount of point given must be 1.0 (one). A rating of 1 to 4 will be given on each significant external factor, to find out how effective the company's current strategy is in responding to these factors, where $4=$ very good response, 3 = above average response, $2=$ average response, and 1 = response below average. Ratings are based on the effectiveness of the company's strategy. (David, 2010)

From the list of available opportunity and threat factors, a critical success factor is determined, and the total points and rating of each factor are determined, as in the table below:

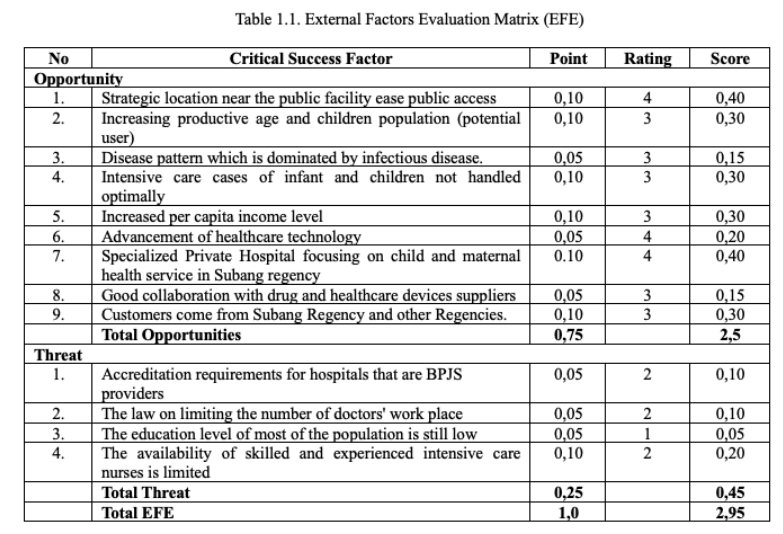

From the list of strengths and weaknesses, then the critical success factors were determined by adding points and rating to each factor, as in the table below: 


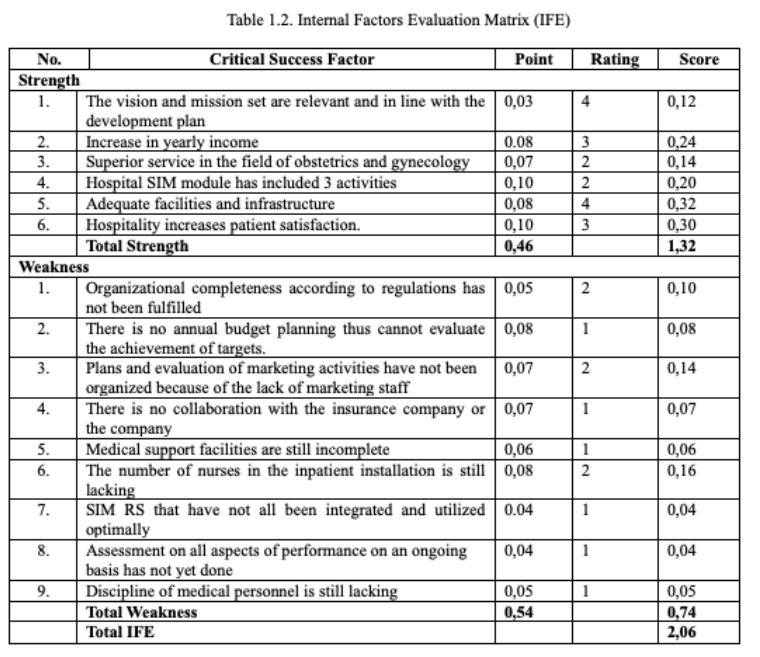

We determine the points of each critical success factor, between 1.0 (very important) to 0.0 (not important). Then, we determine the rating on a 1-4 scale based on the influence of the factors to company condition. Variables that are strengths are rated 1 to 4 (very good) by comparing it with industry or competitor averages while the negative variable is the opposite.

The total value obtained from the IFE matrix is 2.06, and the EFE matrix is 2.95. So based on the IE matrix is in quadrant $\mathrm{V}$ which is Hold and Maintain (maintain and maintain), the recommended strategies are Market Penetration and Product Development.

Based on the TOWS matrix, the opportunities are more significant than threats, and weaknesses are more considerable than internal strengths. So that the TOWS Matrix is in quadrant II, which is the Internal Fixed It Quadrant.

Then the strategy recommendations obtained from the TOWS matrix and IE matrix are Product Development (Product Development), which is a strategy by seeking to increase sales by improving or modifying existing products or services.

From the results of the CDMG, several alternative activities will be developed to become the chosen strategy, which are:

\section{a. Development of HCU / NICU / PICU}

Seeing intensive cases of infants and children that cannot be handled optimally because NICU / PICU services are not yet available in Subang Regency, thus we encourage this product development strategy.

From the profile of the Subang District Health Service Agency, we found that the increase in LBW numbers from 2015 was 699 cases $(2.33 \%)$ to 737 cases $(2.43 \%)$ in 2016. The number of infant mortality in Subang from 2013 to 2017 was $118,131,127,130$, and 126 cases of infant death. From 2013 to 2014, there was an increase of 13 cases $(11.01 \%)$, while from 2016 to 2017 , there was a decrease in the number of infant mortality cases, 4 cases $(3.07 \%)$.

Following the provisions for Class D Hospital and Class C Mother and Child Hospital, intensive services that can be developed are HCU. For class B Mother and Child Hospital, NICU service can also be added in addition to HCU.

\section{b. Development of Child Growth Clinics}

Patients with growth and development disorder are cases that are often referred from the Children's Specialist Clinic because this service is not yet available at Grha Mutiara Maternity Hospital. Based on in-depth interviews with one of the Pediatricians at Grha Mutiara Maternity Hospital, one of the services that need to be developed is a growth and development clinic.

Parents are more alert to growth and development delays and disorders with the Increasing cases of infants and children with the risk of growth and development disorders such as babies born with low weight, babies with congenital infections or babies with health problems during pregnancy that is regularly checked up in the Pediatric Specialist Clinic. The development of the Growth and Development Clinic is needed to monitor appropriate interventions that maintaining the children's quality of life.

c. Development of Internal Medicine and Surgical
Specialist Services

Seeing the number of dominating productive age populations in the Subang Regency and epidemiology of infection cases are still high, specialized physician services have a relatively large market share.

Based on data from the Subang District Health Service Agency, the pattern of ten most inpatient diseases in the Hospital in 2016-2017 is still dominated by infectious diseases, although there are still degenerative diseases such as Hypertension and Diabetes Mellitus. The total number of obstetric outpatient at Grha Mutiara Maternity Hospital, who were referred to the internist during 2018, were 47 cases.

Essential Specialized Medical Services consist of Internal Medicine, Child Health, Surgery, and Obstetrics and Gynecology. That requires the availability of specialized doctor resources, infrastructure, and equipment under applicable provisions. Permenkes No.56 of 2014 concerning Hospital Classification and Licensing stated that Class D Hospital must have at least 2 (two) out of 4 (four) Basic Specialist Medical Services. As for the 
Specialized Hospital for Mothers and Children, in addition to essential medical services, adjunct specialized medical services are also available.

The results of the CDMG said that adding variations in specialist services will increase the number of patient visits so that it impacts on revenue and profit growth.

In the decision-making stage, the chosen strategy uses QSPM (Quantitative Strategic Planning Matrix) to determine priorities that can be implemented using critical success factors on the IFE Matrix and the EFE Matrix. The result of point multiplication and the Attractive Score (AS) with the highest total is the top priority.

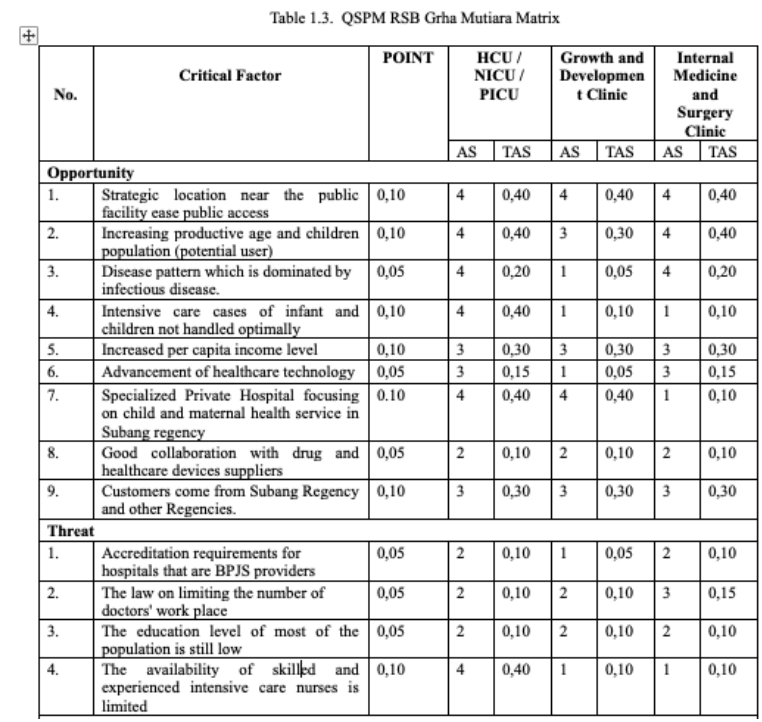

\begin{tabular}{|c|c|c|c|c|c|c|c|c|}
\hline \multicolumn{9}{|c|}{ Strength } \\
\hline 1. & $\begin{array}{l}\text { The vision and mission set are relevant } \\
\text { and in line with the development plan }\end{array}$ & 0,03 & 4 & 0,12 & 3 & 0,09 & 2 & 0,06 \\
\hline 2. & Increase in yearly income & 0.08 & 3 & 0,24 & 3 & 0,24 & 3 & 0,24 \\
\hline 3. & $\begin{array}{l}\text { Superior service in the field of } \\
\text { obstetrics and gynecology }\end{array}$ & 0,07 & 2 & 0,14 & 1 & 0,07 & 1 & 0,07 \\
\hline 4. & $\begin{array}{l}\text { Hospital SIM module has included } 3 \\
\text { activities }\end{array}$ & 0,10 & 1 & 0,10 & 1 & 0,10 & 1 & 0,10 \\
\hline 5. & Adequate facilities and infrastructure & 0,08 & 3 & 0,24 & 3 & 0,24 & 2 & 0,16 \\
\hline 6. & \begin{tabular}{lcc|}
$\begin{array}{l}\text { Hospitality } \\
\text { satisfaction. }\end{array}$ & increases & patient \\
\end{tabular} & 0,10 & 2 & 0,10 & 4 & 0,40 & 3 & 0,30 \\
\hline \multicolumn{9}{|c|}{ Weakness } \\
\hline 1. & $\begin{array}{l}\text { Organizational completeness according } \\
\text { to regulations has not been fulfilled }\end{array}$ & 0,05 & 1 & 0,05 & 2 & 0,10 & 2 & 0,10 \\
\hline 2. & $\begin{array}{l}\text { There is no annual budget planning } \\
\text { thus cannot evaluate the achievement } \\
\text { of targets. }\end{array}$ & 0,08 & 2 & 0,16 & 2 & 0,16 & 2 & 0,16 \\
\hline 3. & $\begin{array}{l}\text { Plans and evaluation of marketing } \\
\text { activities have not been organized } \\
\text { because of the lack of marketing staff }\end{array}$ & 0,07 & 3 & 0,21 & 3 & 0,21 & 4 & 0,28 \\
\hline
\end{tabular}

\begin{tabular}{|l|l|l|l|l|l|l|l|l|}
\hline 4. & $\begin{array}{l}\text { There is no collaboration with the } \\
\text { insurance company or the company }\end{array}$ & 0,07 & 3 & 0,21 & 2 & 0,14 & 3 & 0,21 \\
\hline 5. & $\begin{array}{l}\text { Medical support facilities are still } \\
\text { incomplete }\end{array}$ & 0,06 & 4 & 0,24 & 2 & 0,12 & 4 & 0,24 \\
\hline 6. & $\begin{array}{l}\text { The number of nurses in the inpatient } \\
\text { installation is still lacking }\end{array}$ & 0,08 & 4 & 0,32 & 1 & 0,08 & 3 & 0,24 \\
\hline 7. & $\begin{array}{l}\text { SIM RS that have not all been } \\
\text { integrated and utilized optimally }\end{array}$ & 0.04 & 1 & 0,04 & 1 & 0,04 & 1 & 0,04 \\
\hline 8. & $\begin{array}{l}\text { Assessment on all aspects of } \\
\text { performance on an ongoing basis has } \\
\text { not yet done }\end{array}$ & 0,04 & 2 & 0,08 & 2 & 0,08 & 2 & 0,08 \\
\hline 9. & $\begin{array}{l}\text { Discipline of medical personnel is still } \\
\text { lacking of }\end{array}$ & 0,05 & 2 & 0,10 & 2 & 0,10 & 2 & 0,10 \\
\hline & TOTAL & & & $\mathbf{5 , 7 0}$ & & $\mathbf{4 , 5 2}$ & & $\mathbf{4 , 8 8}$ \\
\hline & PRIORITY & & I & & $\mathbf{I I I}$ & & II \\
\hline
\end{tabular}

On the Determination of the Atractivenes Score (AS) on 1-4 scale, score 1 means the variable is not attractive, or there is no correlation, and score 2 means it is likely to be attractive, or there may be any correlation. Then, score 3 means it is attractive, or there is a correlation, and score 4 means it is the most attractive or most correlated.

The results of the proposed alternative activities QSPM, this is the following priorities:

\section{Development of HCU / NICU / PICU $(5,70)$ \\ 2. Internal Medicine and Surgical Services $(4,88)$ \\ 3. Growth and Development Clinic $(4,52)$}

By considering the condition of the building, the types of services available, human resources, facilities, and infrastructure as well as the available equipment, the plan chosen is to develop Grha Mutiara Maternity Hospital to become the Mother and Child Hospital of Grha Mutiara. After determining the Selected Strategy that is Product Development, then the Strategic Objectives consists of:

1. Equipping Facilities, Infrastructure, and Equipment as RSIA

2. Improving the Quality of Maternal and Child Health Services

3. Increase Revenue to generate Hospital Profits

4. Capturing Market Opportunities for Maternal and Child Health Services

5. Recruiting, Developing and Maintaining Quality HR

\section{Discussion}

Analysis of external factors that will be assessed are:

\section{Government Policy}

BPJS Accreditation requirements that have not yet been met for becoming Advanced Referral Facilities (FKTL) and limiting the number of doctors' workplaces while there is still a limited number of specialist doctors in Subang District pose a threat in the development of Grha Mutiara Hospital Maternity Hospital.

\section{Geography}

The location Grha Mutiara Maternity Hospital is among public facilities such as densely populated 
housing, offices, supermarkets, and educational facilities such as kindergarten, elementary, junior high, high school to Subang University. These conditions make it easier for the Subang community to access services at Grha Mutiara Maternity Hospital and support for service development.

\section{Demographics}

Demographics affect the mindset, behavior of people, and organizations. The population is relatively fast to develop, therefore, organizations that are influenced by population (density or infrequency) are also relatively fast to develop (Rivai, 2015). There are more than 50\% of the productive age population and children in the Subang Regency, which is an opportunity for Grha Mutiara Maternity Hospital to develop its services, especially for productive age and child health.

Hospitals are organizations that are affected by population demographics. With the increase in population, the hospital will be affected by the increasing public demand for health services. The total number of beds is 731 beds for a population of $1,546,000$ people, so the ratio of 1 bed is intended for a 2,115 population. The ratio is still not ideal, according to the Indonesian Ministry of Health, which is 1: 1000. This is an opportunity for Grha Mutiara Maternity Hospital to develop its services.

\section{Epidemiology}

Many diseases found are in a general category. The types of cases vary from febrile to pulmonary TB. So that the development of the hospital should be towards the General Hospital. Nevertheless, if we look at Permenkes No. 340 / MENKES / PER / III / 2010 regarding Hospital Classification, it is stated that the Mother and Child Hospital is required to have 4 (four) primary medical specialties, which is Obstetrics and Gynecology Specialists, Pediatric Health Specialists, Surgical Specialists, and Internal Medicine Specialists. General category diseases can still be managed even in a limited capacity.

The pattern of disease which is dominated by infectious cases and cases of intensive care for infants and children that cannot be handled optimally because NICU and PICU services are not available in the Subang Regency is an opportunity to develop Grha Mutiara Maternity Hospital.

\section{Economy}

A critical economic variable for hospital development opportunities is community income. Most community services are standard goods, so an increase in family income will increase demand for health services (Trisnantoro, 2005). With the increasing economic
81

ncy, it becomes an

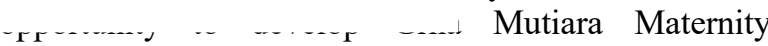
Hospital in meeting the community's need for quality health services.

\section{Education}

The low awareness of the importance of education in the Subang District community, whereas with a higher level of education, will increase the ability to think in absorbing health information. Awareness of the importance of health will also help to make decisions in choosing the right health services. The low level of education is a threat to the development of Grha Mutiara Maternity Hospital.

\section{Technology}

In providing maternal and neonatal health services with rapid development in health technology, can be an opportunity for hospitals as health care providers in providing high-quality services to patients. Many technologies are developing in the field of obstetrics and gynecology, such as Reproductive Health technology in handling infertility, Fetomaternal in the prevention and early detection of genetic diseases, as well as parts of Gynecological Oncology, Reproductive Endocrinology, and Reconstruction Urogynecology. Those developments are currently integrated with a child health service called the Maternal and Child Health Service (PKIA).

The development of health technology that will provide convenience in supporting examinations for diagnostics or in the management of therapies and intervention is an opportunity in the development of Grha Mutiara Maternity Hospital.

\section{Competitors}

The number of hospitals in the Subang Regency is ten hospitals with a total number of beds of 731 beds to a population of $1,546,000$ people, so that the ratio of 1 bed is for 2,115 people. The ratio is still not ideal, according to the Indonesian Ministry of Health, which is 1: 1000 . With only 1 (one) specialized hospital, Grha Mutiara Hospital in Subang, which focuses on maternal and child health services, this is an opportunity in developing Grha Mutiara Maternity Hospital.

\section{Suppliers}

Suppliers for hospitals is ranging from producers of drugs and medical equipment to professional doctors (Trisnantoro, 2005). Good collaboration with suppliers of medicines and medical devices will become an opportunity for the development of Grha Mutiara Maternity Hospital. The limited supply of health workers, particularly in skilled and experienced 
intensive nurses, is a threat to the development of Grha Mutiara Maternity Hospital.

\section{Customers}

The 2017 visitation data of Grha Mutiara Maternity Hospital showed that $99.7 \%$ of outpatient and $89.3 \%$ of inpatient visits are coming from Subang Regency, and $0.3 \%$ are from neighboring districts such as Indramayu, Purwakarta, and Sumedang. All of the patient's visits also dominated by Subang Subdistrict that is $32.8 \%$ of inpatient and $26.8 \%$ of inpatient care. Customers that are not only from Subang Regency but also surrounding areas such as Indramayu, Sumedang, and Purwakarta, which has excellent satisfaction, is an opportunity to develop Grha Mutiara maternity hospital.

Analysis of internal factors that will be assessed are these variables:

\section{Vision and Mission}

With the enactment of Permenkes No. 56 of 2014 for the extension of Grha Mutiara Hospital's maternity hospital operational permit, it is necessary to have a vision and mission if it is going to be developed into a Mother and Child Hospital. The vision and mission that already have been set are relevant because it is following the development goals, and it has superior maternal and child health services that in line with the goals.

\section{Organization}

The success of an organization in the ability to achieve predetermined goals is affected by external and internal organizational factors (Wibowo 2016).

In law No. 44 of 2009 article 33 paragraph 2 states that the organization of the hospital consists of at least the Head of the Hospital or Hospital Director, Medical Services components, Nursing components, elements of Medical Support, Medical Committees, Internal Audit Unit (SPI) and General Administration and Finance. The organizational structure of Grha Mutiara Hospital Maternity, in general, follows the applicable regulations, but there is no Internal Audit Unit (SPI) that has the authority to supervise and nontechnical development within the hospital. The hospital organization is one of the weaknesses because it still needs to add human management resources to comply with applicable regulations.

\section{Finance}

Hospital financial statements describe the financial condition and hospital operational result in a certain period (Suyanto, 2018). Financial statements in the form of a balance sheet, activity report, and cash flow statement can provide information about the overall financial condition of the hospital.

Grha Mutiara Maternity Hospital does not have a budget plan; it is a weakness that needs to be addressed because in achieving the hospital's objectives, one must consider several factors, which are the source of funding used, the potential income from service products, short-term, medium-term and long term income projections. The form of budget planning should be in the form of a Feasibility Study and Business Plan.

\section{4. $\quad$ Marketing}

Market segmentation of Grha Mutiara Maternity Hospital is a productive age woman and elderly who need midwifery and obstetric services in Subang Regency and also 0-14 years old children because there are child health clinic services that provide services for them.

Distribution channels are still limited because there is no collaboration with insurance or companies. The data above shows the absence of marketing is a weakness of Grha Mutiara Maternity Hospital in the development of Grha Mutiara Maternity Hospital.

\section{Health Care Products}

Grha Mutiara Maternity Hospital has a 4D ultrasound service and Perinatal services that can handle category IIA sick babies, which are cares for newborns more than 32 weeks' gestation with physiological immaturity problems with mild disease. These healthcare services are an excellent opportunity to develop Grha Mutiara Maternity Hospital. While unavailable medical support facilities, such as radiology services, are a weakness in the development of Grha Mutiara Maternity Hospital.

\section{Human Resources,}

Human Resources is a vital hospital asset and is a resource that plays a significant role in hospital services (Sabarguna, 2011).

In the Minister of Health Regulation No. 340 / MENKES / PER / III / 2010 regarding Hospital Classification, the development of Grha Mutiara Maternity Hospital to become Class C RSIA requires the addition of Internal Medicine Specialists, Surgical Specialists, and Radiology Specialists. The number of available nurses is four perinatal nurses and three operating room nurses. With the need for 25 nurses, there should be an addition of 18 nurses. While the Responsible Nutrition Workers are currently holding undergraduate Clinical Nutrition degree, it is necessary to add one D1 (diploma 1) Clinical / Dietitian 
Nutritionist.

According to the requirement to become a Class D Public Hospital, it is necessary to add Human resources in essential medical personnel, which are 1 (one) dentist, and at least 2 of 4 Basic Specialists, which are Internal Medicine Doctors and Surgeons. The ratio of nurse and bed hospital is 2:3; thus, with 34 beds, it would need an addition of 6 (six) nurses. Other human resources that need to be added were physical therapists, IPSRS officers, and mortuary officers. Waste management officers' supply is currently collaborating with the Environmental Health Officer from the Health Service.

The lack of personnel in meeting the standards, then based on the results of the CDMG, it is concluded that HR is a weakness in the development of Grha Mutiara Maternity Hospital.

\section{Hospital Information System,}

In Law No.44 of 2009 article 52, it states that the hospital is obliged to record and report on all the activities of the hospital in the form of a Hospital Management Information System. This rule prompted Grha Mutiara Maternity Hospital to start using the Hospital Management Information System (SIM RS) in supporting operations since 2014. An IT officer manages the RS SIM on duty on weekdays. Each module is designed as efficiently as possible for users to use.

Service activities (front office) are integrated with the registration process, the Outpatient process, the Inpatient process, and the patient discharge process. Administrative services (back office) include purchasing, stock of drugs and medical devices, financial management. Meanwhile, the management of human resources is not yet integrated, and the application of SIM RS on laboratory examinations is not optimal because there is no hardware available at the Laboratory Installation

\section{Facilities and Infrastructure}

Following Permenkes No. 340 / MENKES / PER / III / 2010 concerning Hospital Classification for development into RSIA, the infrastructure that must be equipped in outpatient care is the Mother and Child Service Room, the Nursing Room and the Counseling Room. In the Inpatient ward, mothers need additional counseling rooms. Moreover, in the Children Inpatient ward, it needs to add a Children's Care Room and Children's Intervention Room. Other infrastructure facilities that must be completed are the Maternal Isolation Room, IPSRS, and IPLRS. While the operating room needs additional offices and toilets.

The new structured building with adequate facilities and infrastructures and land availability for the construction of new buildings is the strength of the development of the Grha Mutiara Maternity Hospital to become a Mother and Child Hospital.

\section{Service Performance.}

Performance is the appearance of the work of personnel in an organization. It is necessary to evaluate the work of personnel with performance appraisal instruments in order to obtain information on the effectiveness of HR management and for the interest in making decisions on personnel development such as promotion, transfer, rotation, termination, and compensation adjustments (Ilyas, 2012). The 2018 inpatient satisfaction survey with 125 respondents resulted in $88.9 \%$ of the respondents stated that the service was good, $10.8 \%$ was quite good, and $0.3 \%$ was not good.

Registration is still in a manual system where the patient comes and then queuing for a doctor's examination. Grha Mutiara Maternity Hospital has not optimized the technology for text messages notifications to reduce queues in the waiting room, and the disciplines of medical personnel are still needed to increase.

\section{Conclusion}

Based on the strategic plan discussion results in the previous section, the conclusion is that it is currently feasible to develop the Grha Mutiara Maternity Hospital into a Mother and Child Hospital. The background of this development plan is the absence of classification of maternity hospitals in Permenkes No. 56 of 2014, the existence of maternal and infant mortality rates, and infrastructure and human resources that are available today.

Development of Grha Mutiara Maternity Hospital into a Mother and Child Hospital through the preparation using Fred R. David's strategy management model consists of 3 (three) stages, which are the input stage, matching stage, and decision-making stage. The final step is the strategy implementation plan of the chosen strategy with the Balanced Scorecard approach.

The analysis of external factors from the EFE matrix resulted in a score of 2.95, and internal factors of the IFE matrix is 2.06. The matching stage with the TOWS Matrix shows that the position of Grha Mutiara Maternity Hospital is in quadrant II, which is the Internal Fixed It Quadrant, while in the IE matrix, it is in cell $\mathrm{V}$ which is the Hold and Maintain strategy. The chosen strategy is Product Development, then from QSPM analysis resulted in HCU / NICU / PICU service development as a top priority. 


\section{Recommendation}

After determining the objectives of the next implementation strategy, we suggest that:

A. For related institutions

1. Preparation of a feasibility study for the development of the Maternity Hospital into a Mother and Child Hospital.

2. The selected strategy is then developed in an annual program in each section/unit to be implemented and evaluated.

3. Conduct a cost analysis and then prepare a financial and funding plan related to the planned activities

4. In determining intensive service product costs (HCU, NICU, PICU), it is necessary to pay attention to Unit Cost Analysis.

5. Creating a comprehensive marketing plan for available service product marketing.

6. The addition of other specialist services to increase outpatient visits. For example, Internal Medicine Doctors, due to the cases of infection and degenerative diseases that are still high in Subang Regency. Also, adding more surgeons, ENT, and ophthalmologists to increase the utilization of the operating room.

7. Adding more examination services (clinical and radiology laboratories) in both equipment and personnel as supporting services that can increase revenue with operational collaboration.

B. For further research

1. Marketing plan by analyzing the target segmentation of service positions at Grha Mutiara Maternity Hospital.

2. Hospital performance assessment through the application of both unit and individual Key Performance Indicators (KPI).

\section{References}

1. Aditama, Y. Tjandra, 2010. Manajemen Administrasi Rumah Sakit, edisi ke-2. Jakarta: UI Press.

2. Arcan, Mutiara, 2016. Analisis Kelayakan dan
Kesiapan Perubahan Rumah Sakit Awal Bros Panam menjadi Kelas B di Era Jaminan Kesehatan Nasional Tahun 2016. Depok: Tesis- Fakultas Kesehatan Masyarakat, Universitas Indonesia.

3. Ayuningtyas, MARS., Dr. Dumilah, 2015. Perencanaan Strategis Organisasi Pelayanan Kesehatan, edisi ke-2. Jakarta: PT. Raja Grafindo Persada.

4. Azwar, Azrul, 2010. Pengantar Administrasi Kesehatan, edisi ke-3. Jakarta: Binarupa Aksara

5. Badan Pusat Statistik Subang, 2017. Kabupaten Subang dalam Angka 2017, Subang

6. Badan Pusat Statistik Subang, 2017. Kabupaten Subang dalam Angka 2016, Subang

7. Badan Pusat Statistik Subang, 2017. Kabupaten Subang dalam Angka 2018, Subang

8. Data dan Informasi Profil Kesehatan Indonesia 2016 : http://www.depkes.go.id /resources/ download/ pusdatin/profilkesehatan-indonesia/Profil-KesehatanIndonesia-2016.pdf . Diakes 21 Maret 2018

9. Data dan Informasi Profil Kesehatan Indonesia 2018: http://www.depkes.go.id/ resources/download/pusdatin/profilkesehatan-indonesia/Data-danInformasi Profil-Kesehatan-Indonesia2018.pdf

10. David, Fred R. 2010. Strategic Management, Konsep Manajemen Strategis, Buku 1 Edisi 12, terjemahan oleh Dono Sunardi. Jakarta: Penerbit Salemba Empat.

11. Handayani, Tri, 2017. Perancangan Balance Scorecard RS ABC Karawang. Depok: TesisFakultas Kesehatan Masyarakat, Universitas Indonesia.

12. Happy, Anastasia, 2018. Usulan Rencana Strategis RSUD Kota Bekasi Thun 2018-2023. Depok :Tesis-Fakultas Kesehatan Masyarakat, Universitas Indonesia.

13. Herdiyansyah, Haris, 2013. Wawancara, Observasi dan Focus Group sebagai Instrumen Penggalian Data Kualitatif. Jakarta: Raja Grafindo Persada

14. Kaplan R.S. dan Norton D.P., 2000. Balance Scorecard Menerapkan Strategi Aksi. Jakarta: Erlangga.

15. Kotler, Philip, 2009. Manajemen Pemasaran, terjemahan oleh Bob Sabran. Buku 1 Edisi ke13. Jakarta: Erlangga

16. Pearce, John A., Robinson Jr, B.,1997. 
Manajemen Strategis. Formulasi, Implementasi dan Pengendalian. Buku 1. Jakarta: Bina Rupa Aksara.

17. Penelitian Operasional: https://www.yarsi.ac.id/tb-care/pedomanpenelitian-operasionaloperational-research/

18. Permenkes RI No. 56 tahun 2014 tentang Klasifikasi dan Perizinan Rumah Sakit

19. Permenkes RI No. 340 tahun 2010 tentang Klasifikasi Rumah Sakit

20. Permenkes RI No. 147 tahun 2010 tentang Perizinan Rumah Sakit

21. Permenkes RI No. 82 tahun 2013 tentang Sistem Informasi Manajemen Rumah Sakit

22. Profil Dinas Kesehatan Provinsi Jawa Barat 2015

23. Profil Dinas Kesehatan Provinsis Jawa Barat 2016

24. Profil Dinas Kesehatan Kabupaten Subang Tahun 2014

25. Profil Dinas Kesehatan Kabupaten Subang Tahun 2015

26. Profil Dinas Kesehatan Kabupaten Subang Tahun 2016

27. Profil Dinas Kesehatan Kabupaten Subang Tahun 2017

28. Purnomo SE., MBA, Setiawan Hari dan Zulkiflimansyah, PhD, 2007. Manajemen Strategi. Buku Seri Manajemen. Jakarta: Lembaga Penerbit Fakultas Ekonomi Universitas Indonesia.

29. Rangkuti, Freedy, 2014. Analisis SWOT Teknik Membedah Kasus Bisnis. Jakarta: PT. Gramedia Pustaka Utama.

30. Rangkuti, Freedy, 2011. SWOT Balance Scorecard. Teknik Menyusun Strategi Korporat yang Efektif plus Cara Mengelola Kinerja dan Resiko. Jakarta: PT. Gramedia Pustaka Utama.

31. Rivai, Abdul, 2015. Manajemen Strategis Kajian Kepurusan Manajerial Berdasarkan Perubahan Lingkungan Bisnis, Ekonomi, Sosial dan Politik. Jakarta: Mitra Wacana Media

32. Rahadianto, Santo, 2013. Tesis Analisis Rencana Bisnis Rumah Sakit Bersalin Asih Tahun 2013-2018. Depok: Tesis - Fakultas Kesehatan Masyarakat, Universitas Indonesia.

33. Ringkasan Kajian Kesehatan Ibu dan Anak.pdf: https://www.unicef.org/ indonesia/id/A5 B_Ringkasan_Kajian_Kesehatan_REV.pdf Diakses 25 April 2018

34. RS Bersalin Grha Mutiara, 2017. Profil RS
Bersalin Graha Mutiara, Subang

35. RS Bersalin Grha Mutiara, 2013. Laporan Keuangan RS Bersalin Grha Mutiara

36. RS Bersalin Grha Mutiara, 2014. Laporan keuangan RS Bersalin Grha Mutiara

37. RS Bersalin Grha Mutiara, 2015. Laporan keuangan RS Bersalin Grha Mutiara

38. Sinta Dewi, Apriyanti, 2011. Tesis Penyusunan Rencana Strategis Pengembangan Rumah Sakit Bersalin Harapan Bunda Denpasar Tahun 2011-2016. Depok: Tesis - Fakultas Kesehatan Masyarakat, Universitas Indonesia

39. Suryadarmawan, Ede, 2016. Adminstrasi Kesehatan Masyarakat Teori dan Praktik. Jakarta: Rajagrafindo Persada

40. Sugiyono, 2016. Metode Penelitian Manajemen. Jakarta: Alfabeta

41. Tamira, Peter, 2016. Tesis Rencana Pengembangan RSIA JMB Keluarga Ibu menjadi RSU JMB Tangerang tahun 20162020. Depok: Tesis - Fakultas Kesehatan Masyarakat, Universitas Indonesia

42. Tri ariantatik, Monica, 2016. Pengembangan Strategi Bisnis Rumah Sakit Kelas C Tahun 2016-2020 dengan Metode Balace Scorecard (studi kasus Rumah Sakit x Tangerang). Depok : Tesis - Fakultas Kesehatan Masyarakat, UI

43. Trisnantoro, Laksono, 2006. Memahami Penggunaan Ilmu Ekonomi dalam Manajemen Rumah Sakit. Yogyakarta: Gajah Mada University Press

44. Trisnantoro, Laksono, 2018. Jumlah Rumah Sakit di indonesia Pertumbuhan Rumah Sakit Publik.

https://www.persi.or.id/images/2017/litbang /rsindonesia418.pdf

45. Umniyatun, Yuyun, 2013. Rencana Strategis Bisnis RSIA Sammarie Basra Tahun 20132017.Depok: Tesis - Fakultas Kesehatan Masyarakat, Universitas Indonesia

46. Undang-Undang RI No. 44 tahun 2009 tentang Rumah Sakit

47. Undang-Undang RI No. 40 tentang Sistem Jaminan Sosial Nasional

48. Wheelen, Thomas $L$ dan Hunger, J.David, 2003. Manajemen Strategis. Yogyakarta: Penerbit Andi.

49. Wibowo, Adik, 2014. Metodologi Penelitian Praktis Bidang Kesehatan. Depok: Grafindo 